\title{
Campus-Community Partnerships: The Terms of Engagement
}

\author{
Robert G. Bringle* and Julie A. Hatcher \\ Indiana University-Purdue University Indianapolis
}

The emergence of service-learning in higher education and the renewed emphasis on community involvement presents colleges and universities with opportunities to develop campus-community partnerships for the common good. These partnerships can leverage both campus and community resources to address critical issues in local communities. Campus-community partnerships are a series of interpersonal relationships between (a) campus administrators, faculty, staff, and students and (b) community leaders, agency personnel, and members of communities. The phases of relationships (i.e., initiation, development, maintenance, dissolution) and the dynamics of relationships (i.e., exchanges, equity, distribution of power) are explored to provide service-learning instructors and campus personnel with a clearer understanding of how to develop healthy campus-community partnerships.

Historical context, institutional missions, and external expectations for knowledge and expertise have influenced the involvement of American higher education in communities. Higher education has demonstrated community involvement in many ways, including (a) cooperative extension and continuing education programs, (b) clinical and pre-professional programs, (c) top-down administrative initiatives, (d) centralized administrative-academic units with outreach missions, (e) faculty professional service, (f) student volunteer initiatives, (g) economic and political outreach, (h) community access to facilities and cultural events, and most recently, (i) service-learning classes (Thomas, 1998). Unfortunately, however, history has contained too many instances of institutions of higher education treating communities as "pockets of needs, laboratories for experimentation, or passive

\footnotetext{
* Correspondence concerning this article should be addressed to Robert G. Bringle, Department of Psychology, 402 North Blackford Street, Indiana University-Purdue University Indianapolis, Indianapolis, IN 46202 [e-mail: rbringle@iupui.edu].
} 
recipients of expertise" (Bringle, Games, \& Malloy, 1999, p. 9). In response to a record of uneven successes with community involvement, Boyer (1996) challenged higher education to bring new dignity to community engagement by connecting its rich resources "to our most pressing social, civic, and ethical problems, to our children, to our schools, to our teachers, to our cities" (Boyer, 1996, pp. 19-20). This call for civic engagement has awakened renewed interest in promoting institutional citizenship, building new campus-community initiatives, and promoting a broad sense of civic responsibility in higher education (Boyte \& Hollander, 1999; Bringle, Games, \& Malloy, 1999; Zlotkowski, 1996).

This new emphasis on more systematic and comprehensive campus engagement in local communities has been facilitated by a number of factors. Resources made available through federal programs (e.g., HUD Community Outreach Partnership Centers, Federal Work-Study Guidelines including America Reads, Corporation for National and Community Service, National Endowment for the Arts Challenge America Initiative) have provided campuses with funds and technical assistance to create strategic campus-community programs. Experiential and active learning strategies (e.g., service-learning, internships, participatory action research) have placed greater emphasis on providing students with opportunities for hands-on learning experiences in communities. Furthermore, shifts in faculty work emphasize broader definitions of scholarship, including the scholarship of engagement that incorporates research, teaching, and service to the benefit of communities (Boyer, 1996; Bringle, Games, Ludlum, Osgood, \& Osborne, 2000; Bringle, Hatcher, \& Games, 1997; Rice, 1996).

Increasing the number of successful community projects is an important indicator of successful civic engagement. However, we think the quality of the campus-community relationships that are cultivated in the process of project design, implementation, and growth is at least as important as the number of partnerships. Developing better partnerships between the campus and the community is at the heart of renewing community engagement (Kellogg Commission, 1999). However, to date, there is little research on the nature of campuscommunity partnerships (Giles \& Eyler, 1998). This article discusses how the nature of campus-community partnerships can be analogous to and draw from the study of interpersonal relationships by illustrating how psychological theories and constructs from both friendships and romantic relationships are useful in understanding and elucidating some aspects of campus-community partnerships. This analysis by analog, like all analogies, is limited by the appropriateness and applicability of the generalizations. However, we believe that there is merit in applying the analogy because some key constructs in relationships can be explored, awareness of nuances can be made more salient, and recommendations for improved campus-community partnerships can be offered. The usefulness of this analysis, however, will await subsequent research to evaluate suggested hypotheses. 


\section{Service-Learning}

The growth of service-learning on college campuses during the 1990s is one of the clearest indicators of a renewed emphasis on campus-community partnerships. Service-learning is significant because of its implications for stimulating a transition toward healthier and mutually beneficial campus-community partnerships (Zlotkowski, 1996, 1999). Service-learning is defined as a

course-based, credit bearing educational experience in which students (a) participate in an organized service activity that meets identified community needs, and (b) reflect on the service activity in such a way as to gain further understanding of course content, a broader appreciation of the discipline, and an enhanced sense of civic responsibility. (Bringle \& Hatcher, 1995, p. 112)

High quality service-learning classes demonstrate reciprocity between the campus and the community because the service activity is designed and organized to meet both the learning objectives of the course and the service needs identified by the community agency. Successful service-learning classes emphasize the importance of and respect for the role that staff in community-based agencies have as co-educators. Planning, orientation, training, supervision, and evaluation are key aspects of a successful service-learning experience (Cotton \& Stanton, 1990), and each of these components requires effective communication among all parties involved.

Collaboration among a diverse group of stakeholders (in service learning) is a clear example of 'the whole being greater than the sum of its parts.' It requires a special tripartite partnership among students, faculty and the community solidified by strong, trusting relationships. However, building those relationships is one of the most challenging aspects of any partnership. (Torres, 2000, p. 13)

The nature of service-learning provides a high standard to which the entire spectrum of campus-community partnerships can be held.

\section{Campus-Community Partnerships Conceptualized as Relationships}

An examination of campus-community partnerships as relationships can take place at the personal level where a relationship develops between individuals (e.g., faculty, agency personnel, community residents, students; see Nadler, this issue), or at the institutional level (e.g., a department, a community-based agency). In both cases, partnerships exist that vary in the qualities they contain and perpetuate. By critically examining the theory and research on the phases and dynamics of relationships, a better understanding of institutional and personal action steps that might be taken to initiate, develop, maintain, and nurture a healthy partnership with the community can be identified.

Campus-community partnerships are complex, in part, because of the cultural differences that exist between higher education and the community in terms of 
how each generates knowledge and solves problems (Bender, 1993):

Academicians view knowledge as residing in specialized experts, including disciplinary peers who are geographically dispersed; community residents view knowledge as being pluralistic and well distributed among their neighbors. Faculty are stereotyped (possibly with good reason) as being isolated, contemplative, theoretical, cautious, and moving at the slow pace Holland calls "university time"; community leaders are action oriented, focused on results, expansive in looking for local resources, and responsible for making daily decisions about their communities. (Bringle et al., 1999, pp. 9-10)

Morton (1995) observes that campus-community partnerships are too often rooted in charity rather than justice. Charity occurs when resources and surplus are given from one community to another community (see Nadler, this issue), whereas justice is demonstrated when resources are considered as mutual resources and shared among members of the same community. Traditionally, faculty have viewed their professional work as separate from local communities (Bender, 1993; Keener, 1999) and they use a charity model, rather than a justice model, when working with community partners (Morton, 1995). Benson, Harkavy, and Puckett (2000) note that the expert model, which is frequently used by faculty members, is one in which the relationships are elitist, hierarchical, and unidimensional (also see Nadler, this issue) rather than collegial, participatory, cooperative, and democratic. According to Bender (1993), the academy has become a world that is less accessible and more isolated from the public sphere, qualities that complicate its respect for other forms of knowledge construction. These cultural differences become significant challenges for effective communication, respect, and coordinated action toward mutual goals and shared vision.

\section{Relationship Initiation}

Campus-community partnerships, like other relationships, have starting points. These starting points can be serendipitous or planned. Some partnerships may unintentionally grow out of crises (e.g., natural disaster), be arranged through third parties (e.g., city government connects the campus and a community organization to work on a project), or occur through coincidence (e.g., both parties attend a meeting with a common interest). A request from a community agency that is seeking volunteers can hold the potential for an enduring partnership. This suggests that campuses, as well as community agencies, must develop infrastructure (e.g., centralized office, policies, procedures, staff) with the capacity to evaluate and respond to unanticipated opportunities for forming partnerships with differing levels of formality, varying projected time frames, and multiple purposes (Walshok, 1999).

Concerning planned attempts to initiate a relationship, two tasks exist for each member of the potential relationship (Wright, 1999): (1) "deciding what type of relationship we would like to pursue (if any) and, (2) conveying our interest (or lack of interest) to the other person" (p. 39). In romantic relationships, it is estimated 
that about 50 percent of potential mates are eliminated from consideration by exclusionary criteria; after that, selection is based on idiosyncratic criteria (Lykken $\&$ Tellegen, 1993). There are many partnerships that are potentially available and are considered by community agencies as well as campus units, but only a subset of them receive attention that promotes their development. Some potential community partners are identified because they are unique (e.g., there is only one School of Education, there is only one public school system). Other potential community partners receive attention because of a particular need (e.g., a homeless shelter is needed for a service-learning class; a community agency approaches a department to identify ways to improve water quality), their characteristics appeal to decision makers (e.g., proximity, United Way funded agency), or they are aligned on a common interest (e.g., environmental issues).

Relationship initiation requires a means of effectively evaluating and communicating information about the potential rewards and costs that might be expected and having the capacity to fulfill each other's expectations (Kelley \& Thibaut, 1978; Rusbult, 1983). These tasks highlight the importance of accurate self-awareness, communication, and self-disclosure when initiating and developing relationships (Duck, 1988, 1994; Murray, Holmes, Griffin, Bellavia, \& Rose, 2001). In order to self-disclose effectively during the early phases of a campus-community partnership, a clear sense of identity and purpose (e.g., a mission statement, program priorities, strategic plan, learning objectives), procedures (e.g., policies, service-learning contracts, liability issues, evaluation of student performance), and resources (e.g., personnel, facilities, time) need to exist and be effectively communicated to the other party (Walshok, 1999).

Furthermore, this analysis suggests that each party will benefit from having a clear idea about what types of partnerships are mutually beneficial and what types of partnerships are unsuitable (e.g., inconsistent with mission and values, insufficient resources), so that these limitations and their rationale can be communicated when it is appropriate to say "no" or "not now" to a potential relationship. To do so effectively means that each party would do well to develop a template of issues against which to evaluate potential partnerships.

Implications for practice. Based upon this analysis of initiating relationships, we have identified the following implications for service-learning instructors and staff in centralized campus offices who facilitate civic engagement:

- Clear mission: Having a clear identity of purpose and goals (e.g., campus mission, service-learning class objectives, service needs of agency) can provide a basis for selecting among potential partnerships and informing partners about expectations (Beck et al., 2000; Holland, 1999).

- Campus clearinghouse: Partnership initiation is facilitated by a centralized unit that can compile and provide clear information on campus units, programs, and persons who might partner with community agencies as well 
as information on community agencies that are willing to collaborate with faculty and host students (Bringle \& Hatcher, 2000; Gray et al., 1998).

- Compatibility: Campus faculty and staff as well as community representatives should be advised that values, goals, and objectives shape the evaluation of potential partnerships (Duck, 1994). When there is significant relationship incompatibility, it may be best to not begin a partnership.

- Effective communication: Campus staff, students, and faculty must be sensitive to community concerns, provide an open and honest account of campus and departmental resources that can be contributed to building a partnership (Freeman, 2000), remain open to diverse opinions, and have the capacity to respond in a timely manner to community concerns (e.g., return phone calls from the community).

- Skilled staff: Campuses may need to hire professional staff skilled in understanding communities and acting as liaisons among diverse constituencies (Walshok, 1999). These professionals can provide faculty, students, and staff with a better understanding of communities, including information on community assets rather than community needs (Kretzmann \& McKnight, 1993). When conflicts need to be resolved, these individuals can act as a mediator to facilitate communication and problem solving.

\section{Relationship Development and Maintenance}

Research on close relationships indicates that relationship development is not linear. Some relationships develop quickly, while others grow in spurts over time (e.g., Arriaga, 2001; Surra, 1987). Furthermore, not all relationships have the same goals or duration. Many relationships are limited in scope (e.g., relationship to one's auto mechanic), but, nonetheless, mutually worthwhile, whereas others are more intensive and extensive (e.g., relationship to one's spouse). In all cases, though, the interplay of interactions and outcomes between the two parties influences perceptions of equity, satisfaction, and commitment.

Exchange theory (e.g., Kelley \& Thibaut, 1978; Rusbult, 1980, 1983) posits that outcomes (rewards minus costs) must exceed what is minimally expected (comparison level) for a relationship to be initiated and maintained. Satisfaction with a relationship varies directly with the degree to which outcomes exceed what is minimally expected. In addition to being able to initiate relationships and disclose personal information, relationship competencies that promote relationship development and maintenance include (a) appropriately asserting displeasure with others, (b) providing emotional support and advice, and (c) managing interpersonal conflict (Buhrmester, Furman, Wittenberg, \& Reis, 1988).

Research on closeness of a relationship (Berscheid, Snyder, \& Omoto, 1989), which draws from Kelley et al.'s (1983) analysis of interdependency, identifies three components for describing close relationships: (a) frequency of interaction, 
(b) diversity of interaction, and (c) strength of influence on the other party's behavior, decisions, plans, and goals. Each of these components is necessary to defining a close relationship. Frequent interaction is an important but incomplete index of closeness. According to this model, parties who do many different types of activities together are closer than parties who interact just as frequently, but who always do the same activity together. Campus-community partnerships are closer when they grow beyond the original focus of the partnership (e.g., service-learning students placements), identify additional projects on which to work, and develop a broader network of relationships for collaboration (Milardo, 1982).

In addition to frequency and diversity of interactions, relationships that demonstrate interdependency, bi-lateral influence, and consensual decision making are even closer. For, as Morton (1997) notes, "No self-interest . . . can be authentically shared and no intentional interdependence can emerge as long as the basic institutional relationship assumes that we are members of separate communities" (p. 8). Mature, committed, close relationships are characterized by a transition from (a) a tit-for-tat pattern of appraising personal outcomes according to one's own gains to (b) a consideration of joint outcomes (Kelley, 1979), a communal attitude (Clark \& Mills, 1979), and accommodation (Rusbult, Verette, Whitney, Slovik, \& Lipkus, 1991) that supports mutual trust and a long-term perspective. Although closeness may not be a desirable goal for all campus-community partnerships, it is a dimension that may be useful for understanding all partnerships and an aspiration for some.

Because the outcomes of the relationship will be quantitatively and qualitatively different for each party and the standards against which they are appraised will be unique, the attractiveness of developing and maintaining a relationship will differ for each party. Thus, not only is a relationship evaluated from one's own perspective, but parties also examine what is invested and obtained from the relationship relative to the partner. However, many relationships suffer from the ambiguity generated by not knowing how much the other party contributes to and values the relationship (Swann, Hixon, \& De La Ronda, 1992). This highlights the importance of publicly documenting and communicating the outcomes to all constituencies so that commitment to the relationship can be understood, evaluated, and appreciated (Baucom, 1987).

Equity theory posits that when outcomes are perceived as proportionate to inputs, even when the outcomes are unequal, a relationship is satisfying (Walster, Walster, \& Berscheid, 1978). Thus, campus-community partnerships do not have to be equal in all aspects in order to be acceptable; however, they should be equitable and fair. Inequitable relationships, in which someone is perceived to be over benefited or under benefited, result in distress and either (a) attempts to restore equity by appropriately adjusting investments or (b) strain toward relationship dissolution (Hatfield, Utne, \& Traupmann, 1979; Nadler, this issue).

Social exchange theory defines dependency as the degree to which outcomes from the relationship exceed assumed outcomes available in alternative 
relationships (comparison level for alternatives; Kelley \& Thibaut, 1978). Dependency, then, is the degree to which a party's outcomes would suffer losses if the relationship were to end, for whatever reason, and denotes that one is receiving valued outcomes that cannot be obtained from other parties. Dependency, which is associated with relationship investments and satisfaction, leads to high levels of commitment to the relationship and less likelihood of terminating the relationship (Rusbult, 1980, 1983). When dependency is mutual, it leads to healthy interdependency.

Relative dependency describes the comparative levels of each party's dependency: who invests more, who commits more, who puts more effort into the relationship, and who gains more unique outcomes from the relationship? Waller's (1938) principle of least interest states that the party with the least interest in the relationship has the most power. Conversely, the party with more interest has less power because there is more at stake, more to lose; thus, that party will be more vigilant toward, protective of, and committed to the relationship. Acknowledging that any particular campus-community partnership may have differences in relative dependency and power is important to managing and nurturing the development of healthy campus-community partnerships.

Implications for practice. Based upon this analysis of developing and maintaining relationships, we have identified the following implications for servicelearning instructors and staff in centralized campus offices who facilitate civic engagement:

- Monitoring: Campus staff and service-learning instructors should develop and use effective means of gaining regular feedback from community partners and students about their perceptions of the nature of the campuscommunity partnership (e.g., equity, satisfaction, common goals) and then communicate the feedback on a regular basis to appropriate constituencies (Driscoll, Holland, Gelmon, \& Kerrigan, 1996; Gelmon, 2000). In the case of a service-learning class, this could occur at a meeting midway through the semester between the instructor and agency personnel, and an evaluation at the end of each semester completed by all constituencies.

- Advisory groups: Campus-community partnerships can benefit from incorporating multiple perspectives through community advisory groups to monitor partnerships and guard against inappropriate dependency, power differences in decision making, and exploitation (Freeman, 2000).

- Interdependency: Campuses may develop a few close partnerships that possess frequent interaction on a diverse set of activities and extensive interdependency (e.g., shared governance of projects, grant writing, shared staff positions, community members co-teaching, serving on boards and committees). Likewise, faculty may find it mutually beneficial and rewarding to work towards a multi-faceted partnership with one community 
agency through service-learning, applied research, and professional service to the agency.

- Transformations of appraisals of outcomes: Many campus-community partnerships will have equity, which focuses on each individual's investments and outcomes, as the dominant basis for their evaluation. However, a few close partnerships will move from an exclusively exchange orientation to a more communal one that considers joint outcomes across a long-term perspective.

- Affirmation: Campus staff and faculty should identify effective means for affirming the value of the partnership, including public representations of the partnership (e.g., shared space, public awards) and celebrations of the mutual and individual benefits, successes, and outcomes of the campuscommunity partnership (Keener, 1999).

\section{Relationship Dissolution}

Longevity of relationships is often viewed as a desirable characteristic of campus-community partnerships. However, this matter deserves closer examination because enduring partnerships may be neither close nor healthy (Berscheid et al., 1989). Enduring partnerships may be a symptom of an unhealthy partnership that persists because of increasing or chronic dependency of one party or another (Strube, 1988). That is, a partnership can be maintained because it prevents one of the parties from developing the capacity to be self-sufficient and maintains power differences (see Nadler, this issue). Prolonged dependency and exploitation by either the community or the campus need to be guarded against.

Some partnerships end by design and mutual understanding, and their brevity reflects a clear understanding of purpose and intent. Short-term service to meet an acute need, delivering a course or training module during a specified time, selecting a community site for data collection or a one-time service project, or providing the use of campus facilities for a community event are examples in which both parties mutually agree that a particular partnership has a limited scope and a defined end. Relationships that are of shorter duration and limited scope are more prevalent than close, intensive, and extensive relationships (Milardo, 1982). However, even though they may not turn into close, multi-faceted, ongoing relationships, the limited partnerships are nonetheless mutually significant when they meet articulated goals. In addition, a pattern of success with short-term partnerships can provide the foundation for more extensive collaboration in the future.

Typically, the initial phases of self-disclosure in a relationship are superficial, followed by disclosure of more depth concerning issues associated with values and roles (Murstein, 1987; Taylor, 1968). Thus, partnerships that appear initially promising may uncover reasons that preclude continuation. Duck (1988) identifies ineptitude, rule breaking, deception, lack of interest, and conflict as some of the 
reasons that lead to relationship termination. In addition, there may be precipitating events (e.g., turnover in staff, termination of grant) that alter outcomes and justify dissolution of the partnership (Baxter \& Bullis, 1986).

Friendships and romantic relationships require work and attention in order to maintain and enhance them, and the same is true for campus-community partnerships. It may be appropriate to call upon third party interventions (e.g., external consultants, community development specialists) to overcome rough spots and vulnerabilities in important campus-community partnerships (Klein \& Milardo, 1993). Terminating a misconceived or unsatisfactory partnership may be an appropriate resolution. Unplanned terminations usually have fallout and leave bitterness, particularly after sizeable investments have been made in the partnership (Ahrons $\&$ Wallisch, 1987).

Implications for practice. Based upon this analysis of terminating relationships, we have identified the following implications for service-learning instructors and staff in centralized campus offices who facilitate civic engagement:

- Time: Length of the partnership is not a good indicator of either relationship success or quality (Berscheid et al., 1989). Sometimes, longevity denotes and promotes unhealthy dependency. If there are qualities of the campuscommunity partnership that are no longer healthy (Duck, 1994), it may be best to consider termination.

- Unexpected changes in outcomes: Regularly monitoring partnerships is desirable because it may disclose that a partnership which had initially satisfying qualities, but is no longer meeting expectations, should be discontinued (Driscoll et al., 1996; Gelmon, 2000).

- Graceful termination: Campus staff and faculty should plan for managing partnership termination in a sensitive manner that allows for and encourages the development of more appropriate partnerships in the future.

- Integrity: Faculty, staff, students, and advisory boards should promote qualities that maintain effective communications and positive relationships, and deal appropriately with counterproductive behaviors (Morton, 1997). This may require policy statements that allow for dissolution of the partnership because of lack of compliance (e.g., lack of supervision or training provided by agency staff, grant mismanagement, inadequate service provided by students) or miscommunications about expectations and commitment of resources (e.g., staff time).

- Assessment: Campus staff and service-learning instructors should develop effective procedures for obtaining information about how the qualities of partnerships align with program or course expectations and policies (Driscoll et al., 1996; Gelmon, 2000). 


\section{Conclusions}

There has been relatively limited research and theoretical analysis of campuscommunity partnerships (Giles \& Eyler, 1998). The current analysis through analogy with close relationships provides a context from which testable hypotheses can be generated. This analysis has been deliberately simplified by focusing on only the initiation, maintenance, and dissolution of the dyadic relationship. However, campus-community partnerships involve multiple dyadic relationships that create social networks of campus staff, faculty, students, staff from communitybased organizations, clients of community-based organizations, and residents of various communities. Construing campus-community partnerships as "a series of interpersonal relationships built one on top of the other to create a bond between institutions" (Torres, 2000, p. 14) provides a framework for understanding the give and take, the ups and downs, the fits and starts in a service-learning partnership that are aspects of the growth of any relationship (Arriaga, 2001).

As noted, there are many ways in which students, faculty, departments, schools, and the campus can become involved in communities. However, we contend that the most meaningful way to build campus-community partnerships is through service-learning. Service-learning (a) encompasses the most central part of the mission of higher education, teaching and learning, (b) leads to additional forms of civic involvement that can improve other scholarly activities (Benson et al., 2000), (c) involves faculty and students in educationally meaningful service activities that address community issues, (d) values community agency professionals as co-educators, and (e) requires ongoing dialogue among all partners to ensure successful implementation (Zlotkowski, 1999). Institutionalizing service-learning is a critical step toward developing the engaged campus (Bringle \& Hatcher, 2000; Zlotkowski, 1996, 1999). However, success with service-learning can be viewed as just one component of a broader agenda proposed by Boyer as the scholarship of engagement and the model of the new American college (Bringle et al., 1999; Boyer, 1994, 1996; Glassick, 1999).

One of the most important dialectics in relationships pits the desire to be right against the desire to be liked (Deutsch \& Gerard, 1955). In all relationships, the desire to protect the integrity of the self conflicts with the desire to be in a valued and rewarding relationship. The best relationships are those that are self-affirming and supportive (Katz \& Beach, 2000). Unfortunately, the motives to protect "me" and to support "we" are too often incompatible.

What, then, are the terms of engagement to which campuses and communities can aspire? Successful campus-community partnerships must find ways to preserve the integrity of each partner and, at the same time, honor the purpose of the relationship and the growth of each party. The transformation from each party assessing individual outcomes to interdependency that results in an appraisal of joint outcomes (Kelley, 1979) is an important sign of growth and maturity that can 
be used to evaluate community-campus partnerships. Campus-community partnerships will be most meaningful and enduring when individuals conclude that each is contributing in a meaningful, effective manner to activities that have a positive impact on important civic and campus outcomes (Zimmerman \& Rappaport, 1988).

\section{References}

Ahrons, C. R., \& Wallisch, L. (1987). Parenting in the binuclear family: Relationships between biological and stepparents. In K. Pasley \& M. Ihinger-Tallman (Eds.), Remarriage and stepparenting (pp. 225-256). New York: Guilford.

Arriaga, X. B. (2001). The ups and downs of dating: Fluctuations in satisfaction in newly formed romantic relationships. Journal of Personality and Social Psychology, 80, 754-765.

Baucom, D. H. (1987). Attributions in distressed relations: Can we explain them? In D. Perlman \& S. Duck (Eds.), Intimate relationships (pp. 177-206). Newbury Park, CA: Sage.

Baxter, L. A., \& Bullis, C. (1986). Turning points in developing relationships. Human Communication Research, 12, 469-493.

Beck, B., Newton, G. L., Beversdorf, S. J., Young, S., Wilkie, T., \& Maurana, C. A. (2000). Funding setbacks: Partnership strategies for success. Metropolitan Universities, 11, 11-19.

Bender, T. (1993). Intellect and public life. Baltimore: The Johns Hopkins University Press.

Benson, L., Harkavy, I., \& Puckett, J. (2000). An implementation revolution as a strategy for fulfilling the democratic promise of university-community partnerships: Penn-West Philadelphia as an experiment in progress. Nonprofit and Voluntary Sector Quarterly, 29, 24-45.

Berscheid, E., Snyder, M., \& Omoto, A. M. (1989). The relationship closeness inventory: Assessing the closeness of interpersonal relationships. Journal of Personality and Social Psychology, 57, $792-807$.

Boyer, E. L. (1994). Creating the new American college. Chronicle of Higher Education, p. A48.

Boyer, E. L. (1996). The scholarship of engagement. Journal of Public Service and Outreach, 1(1), 11-20.

Boyte, H., \& Hollander, E. (1999). Wingspread declaration on the civic responsibility of research universities. Providence, RI: Campus Compact.

Bringle, R. G., Games, R., Ludlum, C., Osgood, R., \& Osborne, R. (2000). Faculty Fellows Program: Enhancing integrated professional development through community service. American Behavioral Scientist, 43, 882-894.

Bringle, R. G., Games, R., \& Malloy, E. A. (1999). Colleges and universities as citizens. Boston: Allyn $\&$ Bacon.

Bringle, R. G., \& Hatcher, J. A. (1995). A service-learning curriculum for faculty. Michigan Journal of Community Service Learning, 2, 112-122.

Bringle, R. G., \& Hatcher, J. A. (2000). Institutionalization of service learning in higher education. Journal of Higher Education, 71, 273-290.

Bringle, R. G., Hatcher, J. A., \& Games, R. (1997). Engaging and supporting faculty in service learning. Journal of Public Service and Outreach, 2, 43-51.

Buhrmester, D., Furman, W., Wittenberg, M. T., \& Reis, H. T. (1988). Five domains of interpersonal competence in peer relationships. Journal of Personality and Social Psychology, 55, 9911008.

Clark, M. S., \& Mills, J. (1979). Interpersonal attraction in exchange and communal relationships. Journal of Personality and Social Psychology, 37, 12-24.

Cotton, D., \& Stanton, T. K. (1990). Joining campus and community through service learning. In S. I. Delve, S. D. Mintz, \& G. M. Stewart (Eds.), Community service as values education (pp. 101-109). San Francisco, CA: Jossey-Bass.

Deutsch, M., \& Gerard, H. B. (1955). A study of normative and informational social influence upon individual judgment. Journal of Abnormal and Social Psychology, 51, 629-636.

Driscoll, A., Holland, B., Gelmon, S., \& Kerrigan, S. (1996). An assessment model for servicelearning: Comprehensive case studies of impact on faculty, students, community, and institution. Michigan Journal of Community Service Learning, 3, 66-71. 
Duck, S. W. (1988). Relating to others. Chicago: Dorsey.

Duck, S. W. (1994). Meaningful relationships. Thousand Oaks, CA: Sage.

Freeman, E. (2000). Engaging a university: The CCHERS experience. Metropolitan Universities, 11, 20-27.

Gelmon, S. B. (2000). How do we know that our work makes a difference? Assessment strategies for service learning and civic engagement. Metropolitan Universities, 11, 28-39.

Giles, D. E., Jr., \& Eyler, J. (1998). A service-learning research agenda for the next five years. In R. Rhoads \& J. Howard (Eds.), Academic service learning: A pedagogy of action and reflection (pp. 65-72). San Francisco: Jossey-Bass.

Glassick, C. E. (1999). Ernest L. Boyer: Colleges and universities as citizens. In R. G. Bringle, R. Games, \& E. A. Malloy (Eds.), Colleges and universities as citizens (pp. 17-30). Boston: Allyn \& Bacon.

Gray, M. J., Ondaatje, E. H., Fricker, R., Geschwind, S., Goldman, C. A., Kaganoff, T., Robyn, A., Sundt, M., Vogelgesand, L., \& Klein, S. P. (1998). Coupling service and learning in higher education: The final report of the evaluation of the Learn and Serve America, Higher Education Program. Santa Monica, CA: The RAND Corporation.

Hatfield, E., Utne, M. K., Traupmann, J. (1979). Equity theory and intimate relationships. In R. L. Burgess \& T. L. Huston (Eds.), Social exchange in developing relationships (pp. 99-133). New York: Academic Press.

Holland, B. A. (1999). From murky to meaningful: The role of mission in institutional change. In R. G. Bringle, R. Games, \& E. A. Malloy (Eds.), Colleges and universities as citizens (pp. 48-73). Boston: Allyn \& Bacon.

Katz, J., \& Beach, S. R. H. (2000). Look for love? Self-verification and self-enhancement effects on initial romantic attraction. Personality and Social Psychology Bulletin, 26, 1526-1539.

Keener, M. S. (1999). Strengthening institutional engagement: Addressing faculty issues to facilitate change. Journal of Public Service and Outreach, 4, 29-36.

Kelley, H. H. (1979). Personal relationships: Their structure and processes. Hillsdale, NJ: Erlbaum.

Kelley, H. H., Berscheid, E., Christensen, A., Harvey, J. H., Huston, T. L., Levinger, G., McClintock, E., Peplau, L. A., \& Peterson, D. R. (1983). Close relationships. San Francisco, CA: Freeman.

Kelley, H. H., \& Thibaut, J. W. (1978). Interpersonal relationships: A theory of interdependence. New York: Wiley-Interscience.

Kellogg Commission on the Future of State and Land-Grant Institutions. (1999). Returning to our roots: The engaged institution. Washington, DC: National Association of State Universities and Land-Grant Colleges.

Klein, R., \& Milardo, R. M. (1993). Third-party influence on the management of personal relationships. In S. Duck (Ed.), Social context and relationships (Vol. 3, pp. 55-77). Newbury Park, CA: Sage.

Kretzmann, J. P., \& McKnight, J. L. (1993). Building communities from the inside out: A path toward finding and mobilizing a community's assets. Evanston, IL: Center for Urban Affairs and Policy Research, Northwestern University.

Lykken, D. T., \& Tellegen, A. (1993). Is human mating adventitious or the result of lawful choice? A twin study of mate selection. Journal of Personality and Social Psychology, 65, 56-68.

Milardo, R. M. (1982). Friendship networks in developing relationships: Converging and diverging social environments. Social Psychology Quarterly, 45, 162-172.

Morton, K. (1995). The irony of service: Charity, project and social change in service-learning. Michigan Journal of Community Service Learning, 2, 19-32.

Morton, K. (1997). Campus and community at Providence College. In Expanding boundaries: Building civic education within higher education (Vol. II, pp. 8-11). Washington, DC: Corporation for National Service.

Murray, S. L., Holmes, J. G., Griffin, D. W., Bellavia, G., \& Rose, P. (2001). The mismeasure of love: How self-doubt contaminates relationship beliefs. Personality and Social Psychology Bulletin, $27,423-436$.

Murstein, B. (1987). A clarification and extension of SVR theory on dyadic pairing. Journal of Marriage and the Family, 49, 929-933.

Rice, R. E. (1996). Making the place for the new American scholar (Working paper services: Inquiry \#1). Washington, DC: American Association for Higher Education.

Rusbult, C. E. (1980). Commitment and satisfaction in romantic associations: A test of the investment model. Journal of Experimental Social Psychology, 16, 172-186. 
Rusbult, C. E. (1983). A longitudinal test of the investment model: The development (and deterioration) of satisfaction and commitment in heterosexual involvements. Journal of Personality and Social Psychology, 45, 101-117.

Rusbult, C. E., Verette, J., Whitney, G. A., Slovik, L. F., \& Lipkus, I. (1991). Accommodation processes in close relationships: Theory and preliminary empirical evidence. Journal of Personality and Social Psychology, 60, 53-78.

Strube, M. J. (1988). The decision to leave an abusive relationship: Empirical evidence and theoretical issues. Psychological Bulletin, 104, 236-250.

Surra, C. A. (1987). Reasons for changes in commitment: Variations by courtship style. Journal of Social and Personal Relationships, 4, 17-33.

Swann, W. B., Jr., Hixon, J. G., \& De La Ronda, C. (1992). Embracing the bitter "truth": Negative self-concepts and marital commitment. Psychological Science, 3, 118-121.

Taylor, D. A. (1968). Some aspects of the development of interpersonal relationships. Social penetration processes. Journal of Social Psychology, 75, 79-90.

Thomas, N. (1998). The institution as a citizen: How colleges and universities enhance their civic roles. (Working paper \#22.) Boston: New England Resource Center for Higher Education, University of Massachusetts, Boston.

Torres, J. (2000). Benchmarks for campus/community partnerships. Providence, RI: Campus Compact. Waller, W. (1938). The family: A dynamic interpretation. New York: Dryden.

Walshok, M. L. (1999). Strategies for building the infrastructure that supports the engaged campus. In R. G. Bringle, R. Games, \& E. A. Malloy (Eds.), Colleges and universities as citizens (pp. 74-95). Boston: Allyn \& Bacon.

Walster, E., Walster, G. W., \& Berscheid, E. (1978). Equity: Theory and research. Boston: Allyn \& Bacon.

Wright, D. E. (1999). Personal relationships. Mountain View, CA: Mayfield.

Zimmerman, M. A., \& Rappaport, J. (1988). Citizen participation, perceived control, and psychological empowerment. American Journal of Community Psychology, 16, 725-750.

Zlotkowski, E. (1996). A new voice at the table? Linking service learning and the academy. Change, 28(1), 20-27.

Zlotkowski, E. (1999). Pedagogy and engagement. In R. G. Bringle, R. Games, \& E. A. Malloy (Eds.), Colleges and universities as citizens (pp. 96-120). Boston: Allyn \& Bacon.

ROBERT G. BRINGLE (Ph.D., social psychology, University of Massachusetts) is Chancellor's Professor of Psychology and Philanthropic Studies, and Director of the IUPUI Center for Service and Learning. As a social psychologist, he has conducted research on jealousy in close relationships and on educational programs for psychology undergraduates. More recently, his scholarship has focused on implementing and institutionalizing service learning, the role of service in the academy, and institutional change to support community engagement. He is editor of With Service in Mind: Concepts and Models for Service-Learning in Psychology (with D. Duffy), and Colleges and Universities as Citizens (with R. Games \& E. Malloy). Bringle received the Thomas Ehrlich Faculty Award for Service Learning in 1998.

JULIE A. HATCHER (M.S., education, Indiana University) is Associate Instructor, IU School of Education and School of Liberal Arts, and Associate Director, Center for Service and Learning. She has been instrumental in developing and conducting service learning programs and a service-based scholarship program on the IUPUI campus. She is editor of Service Learning Workshop Curriculum Guide (with C. Ludlum Foos), Developing Dynamic Tutors: A Supplemental Guide for Training Reading Tutors, and Service Learning Tip Sheets: A Faculty Resource Guide. 